\title{
CATLIN AND HIS NORTH AMERICAN INDIAN GALLERY AND MUSEUM
}

\author{
By L. J. P. GASKIN
}

$\mathrm{F}^{\mathrm{E}}$ EBRUARY $l$ is the centenary of the opening of "Catlin's North American Indian Gallery and Museum" in the Egyptian Hall, London. George Catlin, American artist, traveller, and ethnographer, spent eight years, 1830-38, among the Plains Indians of North America, and was familiar with their life and customs at a time when the Indians were still living far from that civilization which was to overtake and destroy them so rapidly. His declared purpose from the outset was to preserve for posterity the likeness of aboriginal man in America, and his artistic ability and industry in this direction was shown to great advantage by more than six hundred portraits and sketches of the Indians, and of Indian life, hung round the walls of the Egyptian Hall. The Museum contained thousands of objects of Indian manufacture such as weapons, costumes, musical instruments, and domestic utensils so arranged as to form a pictorial history of those tribes thought particularly worthy of notice. In the centre of the room was erected a large wigwam from the country of the Crow Indians, made of buffalo skins, curiously ornamented with porcupine quills, and capable of housing eighty persons.

The history of the exhibition is interesting. After a four-year sojourn in London and the provinces it was removed to Paris, where it attracted the attention of Louis Philippe, who permitted it to be shown in the Louvre. Unfortunately, this Royal interest involved
Catlin in great difficulties when the July Revolution of 1848 compelled him to leave France. Once again in London, he sought to recoup his losses by the rehabilitation of his exhibition, and this led to financial disaster: his collections were seized for debt, though they were freed later through the generosity of a fellow-countryman.

In 1852, Catlin set out on his travels once again, and on this occasion visited Central and South America. He returned to Europe in 1858, and busied himself with the formation of his "Cartoon Collection", copies of his original pictures, and much new matter from his later travels. He returned to America in 1870 to show this second collection in the Smithsonian Institution, and died in 1872 .

For forty-two years he had laboured to improve and perfect his Indian collections, and to plead the Red Man's cause. His writings, particularly his "Letters and Notes on the manners, customs, and condition of the North American Indians" (1841), made him and his work known to a large circle of readers in Europe and America, and his portraits and sketches have been declared, by those well qualified to judge, as among the most truthful of the Red Indians ever presented to the public. But the most enduring monument to his memory will always be his two collections, now housed in the United States National Museum and the American Museum of Natural History.

\section{NEWTON'S KNOWLEDGE OF THE RADIUS OF THE EARTH}

$\mathrm{I}^{\mathrm{N}}$ a paper entitled "The Story of Newton's Inverse Square Law and his Use of a False Radius of the Earth" (J. Brit. Astro. Assoc., 50, 2; 1939), John Miller states that the story of Newton's alleged ignorance of the true radius of the earth is open to considerable doubt. The data at the disposal of Newton were the time the moon required to revolve around the earth and the moon's distance from the earth in terms of the earth's radius. The latter was known from the days of Greek astronomy to be about 60, and this was independent of the true radius of the earth. A few simple formulæ are derived by Mr. Miller, and from these a relationship is established between the true radius of the earth and certain constants, the basic assumption being the inverse square law. Miller's final formula enables the true radius of the earth to be found, but, of course, if a false value of the radius is used in this formula, the equality breaks down; in other words, the inverse square law seems invalid. It is alleged that Newton took the radius of the earth to be 3,440 miles, and as it was impossible to fit this value in with the inverse square law, his work was delayed nearly twenty years.

It is generally believed that Newton accepted the value of one degree of latitude as 60 miles, hence his difficulty with the fictitious radius of the earth, but, as Miller points out, Snell's measurement in 1617 gave $66 \cdot 6$ miles and Norwood showed in 1637 that 69.5 miles was a close value, while two years later Picard found a more accurate result, slightly less than Norwood's. It is remarkable that Newton did not make use of any of these in 1665-66 when he was engaged on his gravitational theory at Woolsthorpe. It is certain that he knew Snell's value in 1672 , ten years before he was supposed to have recomputed his earlier results, because Varen's "Geography", published in 1672, contains an error which Newton corrected by using Snell's value for the length of a degree of latitude. Picard's accurate results were communicated to the Royal Society in 1672 on the day that Newton was elected a fellow, yet the story goes that he did not make any use of these until 1682. This delay of ten years seems inexplicable.

From an examination of the evidence from various other points of view, Mr. Miller concludes that the story is unauthenticated and that the real reason for Newton's delay of seventeen years in the publication of his "Principia" was the difficulty that he experienced in dealing with axial rotation, a problem to which Miller hopes to return in a subsequent paper. 